\title{
Promoting the inclusion of vital-capacity data in the bronchodilator response
}

This article was published in the following Dove Press journal:

International Journal of COPD

24 April 2017

Number of times this article has been viewed

\section{Helmi Ben Saad}

Laboratory of Physiology, Faculty of Medicine of Sousse, University of Sousse, Tunisia
Correspondence: Helmi Ben Saad Laboratory of Physiology, Faculty of Medicine of Sousse, University of Sousse, Street Mohamed Karoui, Sousse 4000, Tunisia

$\mathrm{Tel}+21698697024$

$\mathrm{Fax}+21673224899$

Email helmi.bensaad@rns.tn

\section{Dear editor}

I read with interest the manuscript of Torén et al ${ }^{1}$ asking for a change in the interpreting way of the reversibility test. The authors have opted for a difference between the predicted normal values after and before bronchodilation (ABD, BBD, respectively). ${ }^{1}$ They have included three spirometric data (forced expiratory volume in the first second $\left[\mathrm{FEV}_{1}\right]$, forced vital capacity $[\mathrm{FVC}]$ and slow vital capacity $[\mathrm{SVC}]$ ), and they have proposed three thresholds to be significant at 9, 4 and 6\%, respectively, for FEV, FVC and SVC. Such papers are encouraged since vital-capacity (FVC and SVC) data are still "neglected" by the Global Obstructive Lung Disease (GOLD). ${ }^{2}$ Moreover, in the GOLD 2017 Report, it was clearly stated that "assessing the degree of reversibility of airflow limitation does not aid the diagnosis of COPD, differentiate COPD from asthma, or predict the long-term response to treatment." However, the following three points should be highlighted:

Point 1 concerns the expression of ABD data in units of percentage predicted normal. This method could be a source of confusion for clinicians. First, almost all the spirometric norms were established for BBD data, and up to day, only two ABD spirometric norms were published. ${ }^{3,4}$ It appears that the use of $\mathrm{BBD}$ instead of $\mathrm{ABD}$ reference values gives $3.2 \%$ of false-negative diagnosis of airflow obstruction. ${ }^{4}$ Second, it seems that ABD prediction equations gave higher predicted spirometric data than existing BBD equations and that bronchodilators' (BD) response decreased with age. ${ }^{3}$ So for that reason, to better understand how patients with chronic respiratory conditions respond to BDs, it will be more helpful to derive ABD norms from healthy and sick subjects. ${ }^{5}$

Point 2 concerns the inclusion of FVC and SVC as clinical outcomes measure of $\mathrm{BD}$ reversibility. This forgotten message from $\mathrm{GOLD}^{2}$ should be promoted from now on. First, the acute FVC response to BD was significantly correlated with numerous health-related quality-of-life items and activities of daily living, which was not the case for the FEV response. $^{5}$ Second, an improvement in $\mathrm{FVC}$ provides useful information about the function of small airways, the most important sites of inflammatory and remodeling processes that are difficult to measure. ${ }^{5}$ Third, the assessment of vital-capacity data was proposed as a means to obtain additional information regarding hyperinflation. ${ }^{5}$

Point 3 concerns the extent of the BD response of the 100 patients with a "likely" mild COPD (their ABD FEV 1 mean was $86 \%$ ). ${ }^{1}$ Comparison with a subgroup of 92 stable COPD patients (GOLD I and II) aged 63 years ${ }^{5}$ found similar data expressed either in absolute terms in $\mathrm{mL}\left(\Delta \mathrm{FVC}: 209 \pm 261 \mathrm{vs} 220 \pm 280^{5} ; \Delta \mathrm{FEV}_{1}: 170 \pm 177 \mathrm{vs}\right.$ $\left.160 \pm 160^{5}\right)$ or as a percentage of the baseline values ( $\% \Delta \mathrm{FVC}$ : $6.0 \pm 7.7$ vs $8.0 \pm 11.0^{5}$; $\% \Delta \mathrm{FEV}_{1}: 7.3 \pm 7.6$ vs $\left.9.0 \pm 10.0^{5}\right)$. However, comparison with a subgroup of $76 \mathrm{COPD}$ 
patients (GOLD III and IV) $)^{5}$ found different results concerning $\triangle \mathrm{FVC}(330 \pm 210 \mathrm{~mL}), \Delta \mathrm{FEV}_{1}(110 \pm 120 \mathrm{~mL}), \% \Delta \mathrm{FVC}$ $(18 \pm 13)$ and $\% \Delta \mathrm{FEV}_{1}(13 \pm 13) .{ }^{5}$ It appears that the $\mathrm{BD}$ response was clinically significant in the more severe subpopulation than in the less severe one.

In conclusion, in daily practice, reversibility should be identified using the changes not only in $\mathrm{FEV}_{1}$ but also those of static volumes. Sufficient evidence is now available to justify the promotion of this message.

\section{Disclosure}

The author reports no conflicts of interest in this communication.

\section{References}

1. Torén K, Bake B, Olin AC, et al. Measures of bronchodilator response of FEV1, FVC and SVC in a Swedish general population sample aged 50-64 years, the SCAPIS Pilot Study. Int J Chron Obstruct Pulmon Dis. 2017;12:973-980.
2. Vogelmeier CF, Criner GJ, Martinez FJ, et al. Global Strategy for the Diagnosis, Management, and Prevention of Chronic Obstructive Lung Disease 2017 Report. GOLD Executive Summary. Am J Respir Crit Care Med. 2017;195(5):557-582.

3. Johannessen A, Lehmann S, Omenaas ER, Eide GE, Bakke PS, Gulsvik A. Post-bronchodilator spirometry reference values in adults and implications for disease management. Am J Respir Crit Care Med. 2006;173(12):1316-1325.

4. Pérez-Padilla R, Torre Bouscoulet L, Vázquez-Garcia JC, et al; grupo PLATINO. Valores de referencia para la espirometría después de la inhalación de $200 \mu \mathrm{g}$ de salbutamol [Spirometry reference values after inhalation of 200 microg of salbutamol]. Arch Bronconeumol. 2007;43(10):530-534. Spanish [with English abstract].

5. Ben Saad H, Préfaut C, Tabka Z, Zbidi A, Hayot M. The forgotten message from gold: FVC is a primary clinical outcome measure of bronchodilator reversibility in COPD. Pulm Pharmacol Ther. 2008; 21(5):767-773. 


\section{Author reply Kjell Torén}

Section of Occupational and Environmental Medicine, University of Gothenburg, Gothenburg, Sweden

Corresponednce: Kjell Torén

Section of Occupational and Environmental Medicine, Institute of Medicine, Sahlgrenska Academy, University of Gothenburg, Box 4I4,

S-405 30 Gothenburg, Sweden

$\mathrm{Tel}+46317866262$

Email kjell.toren@amm.gu.se

\section{Dear editor}

We appreciate the comments by Dr Ben Saad and take the opportunity to add a few remarks: 1) The difference between the values after bronchodilatation ( $\%$ predicted normal) minus the value before bronchodilatation ( $\%$ predicted normal) is rather insensitive to the particular reference equation applied to calculate the predicted normal. 2) The final conclusion by Dr Ben Saad that forced vital capacity and slow vital capacity should be included when assessing the effect of bronchodilatation is quite in line with our opinion.

\section{Disclosure}

The author reports no conflicts of interest in this communication.

Dove Medical Press encourages responsible, free and frank academic debate. The content of the International Journal of Chronic Obstructive Pulmonary Disease 'letters to the editor' section does not necessarily represent the views of Dove Medical Press, its officers, agents, employees, related entities or the International Journal of Chronic Obstructive Pulmonary Disease editors. While all reasonable steps have been taken to confirm the content of each letter, Dove Medical Press accepts no liability in respect of the content of any letter, nor is it responsible for the content and accuracy of any letter to the editor.

\section{Publish your work in this journal}

The International Journal of COPD is an international, peer-reviewed journal of therapeutics and pharmacology focusing on concise rapid reporting of clinical studies and reviews in COPD. Special focus is given to the pathophysiological processes underlying the disease, intervention programs, patient focused education, and self management protocols.

\section{Dovepress}

This journal is indexed on PubMed Central, MedLine and CAS. The manuscript management system is completely online and includes a very quick and fair peer-review system, which is all easy to use. Visit http://www.dovepress.com/testimonials.php to read real quotes from published authors.

Submit your manuscript here: http://www.dovepress.com/international-journal-of-chronic-obstructive-pulmonary-disease-journal 